\title{
Pemuliaan Tanaman Padi melalui Pertunjukan Wayang Kulit dalam Upacara Bersih Desa di Geneng, Trucuk, Klaten, Jawa Tengah
}

\author{
Sutiyono Sutiyono ${ }^{1}$, Rumiwiharsih ${ }^{2}$, Bambang Suharjana ${ }^{3}$ \\ 1,2,3 Fakultas Bahasa dan Seni, Universitas Negeri Yogyakarta
}

sutiyono.uny@gmail.com

Penelitian ini bertujuan untuk mendeskripsikan bentuk pemuliaan tanaman padi melalui pertunjukan wayang kulit lakon Dewi Sri dalam upacara Bersih Desa. Pendekatan penelitian yang dipergunakan adalah pendekatan kualitatif. Penelitian ini dilaksanakan di Geneng, Trucuk, Klaten, Jawa Tengah dari bulan Mei hingga September 2017. Sebagai subjek penelitian adalah masyarakat petani Desa Geneng, sesepuh Desa Geneng, dalang wayang kulit, pengrawit, jurukunci makam, penjual makanan, dan peziarah. Cara pengumpulan data ditempuh dengan: observasi, dokumentasi, studi pustaka, dan wawancara. Data penelitian dianalisis dengan tahapan: koleksi data, reduksi data, pemeriksaan data, dan penarikan kesimpulan. Untuk mengetahui keabsahan data dilakukan dengan triangulasi. Hasil penelitian ini menunjukkan, bahwa: (1) Tata cara pemuliaan tanaman padi adalah dengan mengadakan upacara Bersih Desa meliputi pembersihan manusia dan lingkungan secara fisik dan batin di Desa geneng yang disertai doa berssama, (2) Tata cara pemuliaan tanaman padi adalah dengan mempresentasiknan Lakon Dewi Sri dalam pertunjukan wayang kulit, yang mengisahkan bahwa kehidupan manusia sangat tergantung pada kehidupan Dewi Sri yang memberi kesejahteraan umat manusia.

Kata kunci: pemuliaan, padi, upacara, bersih desa, dewi sri.

\section{Rice Breeding through Shadow Puppet Performing Art in Bersih Desa Ritual in Geneng, Trucuk, Klaten, Middle Java}

This study aims to describe the form of rice plant breeding through shadow puppet performing art in Bersih Desa ritual. The research approach used is qualitative approach. The research was conducted in Geneng, Trucuk, Klaten, Central Java from May to September 2017. As the research subjects were farmers of Geneng Village, Geneng village elders, puppeteer puppeteers, pengrawit, jurukunci graves, food vendors, and pilgrims. Data collection is done by: observation, documentation, literature study, and interview. Research data is analyzed by stages: data collection, data reduction, data examination, and conclusion. To know the validity of data is done with triangulation. The expected result of this research is the form of rice plant breeding through wayang kulit kulit play Dewi Sri in Clean Village ceremony is a cultural activity consisting of: (1) Procedure of rice plant breeding is to conduct a physical and mental cleansing ceremony in Geneng Village accompanied by a prayer together, (2) The procedure of rice plant breeding is by presenting Dewi Sri in the wayang kulit show, which tells us that human life is very dependent on the life of Dewi Sri giving the welfare of mankind.

Keywords: breeding, rice, Bersih Desa, Dewi Sri, ritual

Proses Review : 1 - 31 Maret 2018, Dinyatakan Lolos: 10 April 2018 


\section{PENDAHULUAN}

Geneng merupakan salah satu desa di Kecamatan Trucuk, Kebupaten Klaten yang setiap tahun diadakan upacara Bersih Desa. Geneng termasuk desa yang dijadikan sebagai lumbung padi daerah Trucuk, Klaten, di samping Delanggu karena lahan pertaniannya yang luas dan padinya gemuk-gemuk (sawahe jembar-jembar parine lemu-le$m u)$. Masyarakat Geneng sebagian besar adalah petani. Masyarakat selalu bergelut dengan sawah dan hasil pertaniannya yang berupa padi sangat melimpah. Hubungan petani dengan sawah dan tanaman padi bukan hanya sekedar hubungan antara penanam dengan tanaman, tetapi memiliki hubungan spiritual yang sangat kuat. Bagi masyarakat petani di Geneng, tanaman padi memiliki kekuatan magis, sehingga tanaman padi harus dimuliakan atau dihormati oleh masyarakat, dan tidak boleh diperlakukan seenaknya. Dari sejak menanam padi, memanen padi, menjadi gabah, beras, hingga menjadi nasi, masyarakat Geneng sangat memuliakannya. Masyarakat Geneng percaya jika padi tersebut tidak diperlakukan dengan baik, maka yang terjadi adalah malapetaka yang tidak dapat terhindarkan.

Masyarakat petani percaya bahwa padi adalah tanaman yang memiliki kekuatan magis yang mampu mempengaruhi kehidupan manusia karena padi adalah tanaman yang dibawa oleh Dewi Sri. Dalam ungkapan Jawa disebutkan, bahwa "pari iku malati, karana ana sing nduwe, yaiku Dewi Sri" (padi itu membahayakan, karena ada yang punya yaitu Dewi Sri). Para petani percaya bahwa Dewi Sri adalah dewa pembawa kesejahteraan, jadi tanaman yang dibawa oleh sang dewi tersebut adalah tanaman yang akan membawa kesejahteraan bagi masyarakat. Tanaman ini harus diperlakukan dengan baik agar dapat menyejahterakan masyarakat.

Meskipun padi telah berubah bentuk dan sifatnya menjadi beras, dan kemudian beras berubah menjadi nasi, tetapi harus tetap dihormati dengan diperlakukannya secara baik. Masyarakat Geneng selalu mengajarkan untuk memuliakan atau menghormati padi. Salah satunya adalah tidak membiarkan nasi terbuang sia-sia, karena dengan membuang nasi tersebut walaupun dalam jumlah yang sedikit menandakan bahwa ia tidak mensyukuri nikmat. Bahkan ia dianggap telah menghina Dewi Sri. Masyarakat juga percaya bahwa padi atau nasi yang tercecer dan sengaja dibuang akan menangis, dan membuat Dewi Sri akan marah. Dewi Sri akan memberikan hukuman kepada orang yang telah membuang nasi. Menurut masyarakat ia telah mendapat hukuman dari Dewi Sri yang sering disebut kualat.

Dari cerita tersebut masyarakat melihat bahwa tanaman padi itu sakral dan dilindungi oleh Dewi Sri, sehingga harus diperlakukan dengan baik. Padi bagi petani dianggap sebagai sumber kehidupan yang membawa kesejahteraan, sehingga tidak boleh diperlakukan sembarangan. Padi memiliki ibu yang melindunginya yaitu Dewi Sri. Masyarakat akan merasa aman dan tenang ketika di rumah terdapat banyak padi atau beras walaupun tidak memiliki uang. Mereka menganggap bisa tetap hidup dengan hanya memiliki beras, karena beras adalah makanan pokok bagi mereka. Berbeda ketika masyarakat memiliki uang yang banyak namun tidak punya beras. Uang tersebut tidak akan berguna ketika tidak ada beras yang dapat dibeli, sehingga kehidupan mereka akan mandeg.

Oleh karena itu, petani sangat menjaga hubungan harmonis dengan tanaman padi. Hubungan antara petani dan tanaman padi ini juga telah masuk dalam jiwa petani seperti halnya hubungan orang tua dan anak. Masyarakat percaya bahwa apa yang terjadi pada padi itu tergantung pada petani yang menanamnya. Ketika masyarakat menanam padi, mereka harus menjaga sikap dan perilakunya, baik terhadap tanaman padi itu sendiri maupun menjaga keharmonisan dalam kehidupan sosial. Tujuannya agar tanaman padi dapat tumbuh subur, sehingga hasil panennya melimpah. Masyarakat petani mengungkapkan bahwa hasil yang diperoleh petani berupa panen padi yang melimpah, sesungguhnya merupakan hasil perbuatan dan perilaku yang baik dari petani itu sendiri. Hubungan antara petani dan tanaman padi ini telah mengikat kuat dalam jiwa petani sehingga selain mempengaruhi hubungan petani dan padi juga akan memepengaruhi kehidupan sosial masyarakat petani itu sendiri. Masyarakat petani mempercayai bahwa tanaman padi yang dibawa oleh Dewi Sri ini mengajarkan untuk hidup harmonis, baik dengan sesama manusia maupun alam lingkungannya.

Masyarakat petani Geneng memperoleh pengetahuan penanaman dan perawatan padi dari para leluhur berdasarkan pengalamannya. Meskipun sekarang telah terjadi banyak perubahan dalam teknologi pertanian, masyarakat masih mempercayai bahwa padi adalah tanaman yang sakral sebagai sumber kehidupan yang dibawa oleh Dewi Sri. Masyarakat Geneng percaya bahwa padi adalah tanaman yang memiliki kekuatan magis yang mampu mempengaruhi kehidupan manusia karena padi adalah tanaman yang dibawa oleh Dewi Sri sebagai dewa kesejahteraan. Oleh karena itu dilaksanakan upacara pemuliaan tanaman padi melalui pertunjukan wayang kulit dengan Lakon Dewi Sri dalam sebuah upacara Bersih Desa. Pemahaman tentang pertunjukan wayang kulit dengan Lakon Dewi Sri merujuk pada aktivitas-aktivitas 'simbolik' atau 'estetis' khusus, misanya aktivitas-aktivitas ritual, atau teatrikal, dan berbagai aktivitas seni rakyat, yang dijalankan sebagai produk ekspresi yang sengaja di dalam genre produk lokal yang telah mapan (Hughes-Freeland, 1998: 194).

Peristiwa pertunjukan ini disebut oleh Simatupang (2006) sebagai peristiwa ambang batas, yaitu peristiwa yang nyata akan tetapi berbeda dengan yang dijumpai dalam kehidupan sehari-hari. Menurut Turner (1982), orang menik- 
mati dan melakukan pertunjukan atau peristiwa ambang batas tersebut karena di dalamnya berlangsung berbagai hal yang memungkinkan orang untuk merefleksikan berbagai perihal diri, orang lain, masyarakat, dan dunia yang dihidupinya. Demikian juga halnya dengan pertunjukan wayang kulit lakon Dewi Sri dalam upacara Bersih Desa. Pertunjukan wayang kulit Lakon Dewi Sri ini hanya dipertunjukkan apabila telah terjadi pasca panen. Murgiyanto (1996: 153) dan Hendri (2001: 84) menyebut pertunjukan jenis ini sebagai cultural performance (pertunjukan budaya) yang kontekstual, yaitu pertunjukan yang selalu terkait dengan upacara adat yang dilaksanakan masyarakat pendukungnya.

Kehadiran pertunjukan wayang kuli lakon Dewi Sri dalam upacara Bersih Desa merupakan fenomena budaya yang menarik dan unik. Dikatakan menarik karena relevansinya dalam kehidupan masyarakat Geneng, bahwa masyarakat setempat masih memfungsikannya hingga sekarang. Pertunjukan wayang kuli lakon Dewi Sri merupakan penopang wajib dalam tradisi upacara Bersih Desa. Tentu saja tidak ada upacara Bersih Desa yang dilaksanakan tanpa pertunjukan wayang kulit lakon Dewi Sri. Hal ini seperti terjadi di Singkarak, Minangkabau bahwa di dalam Upacara Maanta Padi Saratuih harus dihadirkan musik talempong bundo (Sriwulan, 2014: 56).

Tradisi yang telah lama dilakukan masyarakat hingga sekarang merupakan bentuk aktivitas masyarakat yang termotivasi oleh sesuatu yang tidak kelihatan (kasat mata) dan tidak diketahui sebagai bentuk kontrol susuatu (Nene, 2012: 124). Hal ini menjadi alasan masyarakat petani Geneng bahwa tanaman padi yang dibawa oleh Dewi Sri adalah tanaman yang akan membawa kesejahteraan bagi masyarakat, sehingga tanaman ini harus diperlakukan dengan baik agar mendapat kemuliaan di sisi Tuhan. Dari cerita tersebut masyarakat melihat bahwa tanaman padi ini memang sangat sakral dan dilindungi oleh Dewi Sri, sehingga harus diperlakukan dengan baik. Tanaman padi bagi petani dianggap sebagai sumber kehidupan yang membawa kesejahteraan, sehingga tidak boleh diperlakukan sembarangan.

Penelitian ini bertujuan untuk mengetahui tata cara pemuliaan tanaman padi yang dilakukan masyarakat petani Desa Geneng dalam memperlakukan padi di sawah dan di rumah, melalui: (1) pertunjukan wayang kulit lakon Dewi Sri sebagai bentuk aktivitas budaya memuliakan tanaman padi, (3) prosesi upacara Bersih Desa sebagai bentuk upacara meruat bumi, manusia, dan lingkungan.

\section{METODE PENELITIAN}

Metode yang dipergunakan dalam penelitian ini adalah metode penelitian kualitatif. Melalui metode penelitian kualitatif, berbagai aspek yang diteliti dapat menghasilkan data yang relevan sesuai dengan yang dibutuhkan.
Selain itu, dapat dilakukan observasi dan wawancara yang lebih mendalam terhadap objek-objek penelitian, sehingga data-data yang diperoleh lebih akurat.

Trucuk merupakan salah satu wilayah kecamatan di Kabupaten Klaten, Jawa Tengah yang dijadikan sebagai lokasi penelitian. Di wilayah ini terdapat desa-desa yang setiap tahunnya menyelenggarakan tata cara pemuliaan tanaman padi yang dilakukan masyarakat petani melalui pertunjukan wayang kulit dengan lakon Dewi Sri. Pertunjukan wayang kulit ini harus masuk prosesi upacara Bersih Desa. Di lokasi penelitian ini dijumpai subjek penelitian, antara lain para jurukunci makam, ketua dan sesepuh Desa Geneng, dalang wayang kulit, pengrawit, masyarakat petani Desa Geneng, penjual makanan, dan peziarah.

Instrumen utama dalam penelitian ini adalah peneliti sendiri. Peneliti langsung turun ke lapangan, melakukan observasi di Desa Geneng, Kecamatan Trucuk, Kabupaten Klaten serta melakukan wawancara dengan para informan. Sebelumnya, peneliti telah mempersiapkan diri dengan membawa perbekalan yang siap membantu peneliti selama berada di lapangan. Perbekalan itu di antaranya adalah tape recorder dan buku catatan. Tape recorder dipergunakan untuk merekam jalannya wawancara, dan buku catatan dipergunakan untuk mencatat observasi langsung di lapangan, seperti tata cara pemuliaan tanaman padi yang dilakukan masyarakat petani melalui pertunjukan wayang kulit dengan lakon Dewi Sri. Pertunjukan wayang kulit ini harus masuk prosesi upacara Bersih Desa

Teknik pengumpulan data yang dipergunakan dalam penelitian ini adalah dengan cara melakukan observasi, wawancara, dan dokumentasi. Teknik yang dipergunakan untuk menganalisis data penelitian adalah teknik analisis deskriptif interpretatif dengan langkah-langkah sebagai berikut: (1) Memilih dokumen/data yang relevan dan memberi kode. (2) Membuat catatan objektif, dalam hal ini sekaligus melakukan klasifikasi dan mengedit (mereduksi) jawaban. (3) Membuat catatan reflektif, yaitu menuliskan apa yang sedang dipikirkan peneliti sebagai interpretasi dalam sangkut pautnya dengan catatan objektif. (4) Menyimpulkan data dengan membuat format berdasarkan teknik analisis data yang dikehendaki peneliti. (5) Melakukan triangulasi yaitu mengecek kebenaran data dengan cara menyimpulkan data ganda.

\section{HASIL DAN PEMBAHASAN}

\section{Upacara Bersih Desa}

Upacara Bersih Desa di Desa Geneng selalu dilaksanakan tanggal 20 Saban yang dipergunakan untuk memuliakan tanaman padi merupakan sisa-sisa peninggalan kepercayaan animisme dan Hindu-Budha. Cara ini terus dianut dan dilaksanakan sebagai tradisi masyarakat sebagai wujud syukur kepada Tuhun. Untuk tahun 2017 berlangsung tanggal 20 Saban 1438 H (17 Maret 2017). Pada menjelang 
upacara Bersih Desa, seminggu sebelumnya seluruh warga masyarakat keluar dari rumah untuk berkumpul bersama. Mereka dibagi dalam kelompok-kelompok, antara lain ada kelompok yang membersihkan makam, parit, sungai, sawah, menggali lobang untuk pembuangan sampah, mengecet pagar, dan lain-lainya. Setelah masyarakat membersihkan lingkungan desa secara lahiriah, giliran berikutnya mereka membersihkan hati pada hari yang disepakati, yaitu upacara Bersih Desa tanggal 20 Saban $1438 \mathrm{H}$.

Dalam upacara Bersih Desa, setiap keluarga membawa berkatan pada siang hari. Untuk mempersiapkannya, berkatan dibuat dari hasil bumi tanaman padi dan tanaman lain sebagai hasil pertanian Desa Geneng. Wujud berkatan adalah nasi, lauk, gudangan, jajan pasar, buah-buahan, dan krupuk. Berkatan itu ditaruh pada ancak (wadah dibuat dari bambu yang dianyam) yang dilapisi daun pisang. Kemudian berkatan itu dibawa untuk ditaruh di atas tikar plastik yang dibentang di jalan dengan panjang sekitar 60 meter, di depan rumah Kepala Desa Geneng.

Pada acara di tingkat desa ini dihadiri hampir seluruh masyarakat Desa Geneng. Setelah mereka duduk di atas tikar menghadap berkatan masing-masing, Kepala Desa Geneng memberi sambutan tentang pentingnya masyarakat mengadakan upacara Bersih Desa, dilanjutkan acara Yasinan (membaca Surat Yasin) dan Tahlilan (membaca doa tahlil) bersama-sama oleh seluruh masyarakat yang hadir dalam upacara Bersih Desa. Kemudian acara slametan dimulai. Modin (pengulu) Desa Geneng membacakan doa secara Islami. Selesainya acara slametan, masyarakat menukar berkatan yang dibawa dengan berkatan milik tetangga untuk dibawa pulang.

Selain dihadiri oleh masyarakat Desa Geneng, juga datang para kerabat dari desa lain dan kerabat yang merantau di Jakarta, Semarang, Bandung, Surabaya, dan luar Jawa. Mereka itu ada hubungannya dengan kulit-daging (pertalian darah). Mereka pulang kampung untuk melakukan doa bersama dan bersilaturahmi dengan keluarga di Desa Geneng.

\section{Biaya Upacara Bersih Desa}

Tujuan kegiatan upacara Bersih Desa yang terpenting adalah dipergunakan untuk memulikan tanaman padi. Oleh karena itu, orang-orang yang memikirkan gawe desa (Bersih Desa dan Pergelaran wayang kulit) adalah para petani. Untuk mendukung kegiatan tradisi gawe desa dibutuhkan biaya yang tidak sedikit. Biaya tersebut diambilkan dari iuran anggota masyarakat di seluruh Desa Geneng. Besarnya iuran dari setiap anggota masyarakat ditentukan menurut status sosial masyarakat petani.

Secara tradisional, status masyarakat pedesaan di Desa Geneng dibedakan atas tigat golongan. Pertama, golongan kuli kenceng yaitu warga masyarakat desa yang memiliki rumah, tanah pekarangan dan sawah. Golongan ini mempunyai hak dan kewajiban penuh atas segala gawe desa dan pemerintahan yang ada di atasnya, serta memiliki kedudukan sosial tertinggi dalam masyarakat desa. Kedua, golongan kuli setengah kenceng yaitu warga masyarakat yang memiliki rumah tetapi tidak memiliki sawah. Golongan ini sering menjadi petani penggarap/penyewa. Secara tradisional, hak dan kewajiban golongan kuli setengah kenceng lebih rendah dibanding kuli kenceng. Ketiga, golongan indhung yaitu warga masyarakat yang hanya memiliki rumah yang didirikan di atas pekarangan orang lain. Kebanyakan mereka hidup sebagai pekerja atau buruh tani pada seorang petani yang mampu. Sebenarnya ada empat golongan, yakni yang keempat, tlosor yaitu mereka yang tidak memiliki rumah, pekarangan, dan sawah. Mereka tinggal dengan keluarga lain (Moertono, 1968: 138). Tetapi di wilayah Desa Geneng tidak terdapat golongan keempat.

Untuk menyelenggarakan pentas wayang pada acara Bersih Desa itu diperlukan dana sekita 20 juta rupiah. Jumlah sebesar ini dipikul oleh seluruh masyarakat desa. Mata pencaharian masyarakat di Desa Geneng sebagaian besar adalah petani, dan sebagian kecil meliputi pegawai negeri sipil berjumlah 22 orang, guru yang prangkap petani 14 orang, pedagang 9 orang, buruh 11 orang, dan serabutan 23 orang. Mereka yang bukan petani ternyata juga ikut membantu demi terlaksananya gawe desa. Hal ini menunjukkan bawa mereka juga ikut memuliakan tanaman padi. Dari seluruh urunan yang masuk terkumpul dana sekitar 20 juta rupiah. Kesanggupan masyarakat untuk mengumpulkan biaya yang cukup besar ini membuktikan bahwa masayarakat desa dalam membangun kerukunan dan persatuan tidak hanya sekadar diucapkan dan hanya sebagai angan-angan saja, tetapi benar-benar diwujudkan dalam bentuk nyata.

Seluruh uang pasok itu dikumpulkan, guna menyelenggarakan upacara Bersih Desa dan pertunjukan wayang kulit. Kenyataannya biaya untuk membiayai produksi pertunjukan wayang kulit dari dulu sampai sekarang belum pernah membuat panitia tombok. Dari jumlah 20 juta rupiah itu, khusus sekitar 10 juta rupiah diberikan kepada dalang wayang kulit bersama para pendukungnya. Selebihnya dipergunakan untuk menyewa sound system dan biaya konsumsi. Konsumsi itu diperuntukkan seluruh pendukung pertunjukan dan masyarakat yang hadir pada malam hari yang menyaksikan pertunjukan.

\section{Makna Bersih Desa}

Bersih Desa mempunyai dua arti. Pertama, ditinjau dari segi jasmaniah, Bersih Desa itu memiliki arti harfiah yaitu masyarakat beramai-ramai membersihkan desa yang sesunguhnya, misalnya membersihkan jalan, makam, sawah, kali, parit, dan selokan. Selain itu juga membuat lubang tanah untuk pembuangan sampah, mengecet pagar, gardu, dan rumah. Keadaan desa secara fisik memang tampak be- 
nar-benar bersih. Kedua, ditinjau dari segi rohaniah, manusia hidup dunia itu ada yang menciptakan, yaitu Tuhan. Manusia perlu membersihkan diri dengan cara bersyukur, karena ia merasa telah diberi Tuhan berujud tanaman padi yang subur.

Masyarakat menganggap bahwa Bersih Desa itu sama dengan rasulan atau syukuran. Rasulan artinya tradisi Bersih Desa itu didoakan dengan cara Islam, yang mengambil doa-doa yang diperintahkan oleh rasul, yaitu Muhammad SAW. Syukuran artinya tradisi Bersih Desa itu selalu menghadirkan hasil bumi melalui tanaman padi atau makanan yang dikeluarkan sebagai sedekah bersama (Yuniarso, 2012). Selain itu juga menghadirkan hiburan dengan pertunjukan wayang kulit lakon Dewi Sri, yang dianggap sebagai bentuk ritual untuk memuliakan tanaman padi, sehingga masyrakat Desa Geneng merasa diberi Tuhan berupa kesehatan, keselamatan, dan rezeki yang cukup. Baik upacara Bersih Desa maupun pertunjukan wayang kulit ini harus dilaksanakan, karena jika tidak dilaksanakan masyarakat Desa Geneng takut akan terjadi musibah besar (Riani, 2012: 15).

Bentuk syukur bersama yang dilakukan masyarakat Desa Geneng itu benar-benar selalu dilaksanakan setiap tahun, dan bukan melulu ucapan lisan. Hal ini berbeda dengan fenomena sekarang, banyak pejabat atau wakil rakyat yang hanya melontarkan sesuatu melalui omong kosong, tetapi kenyataannya tidak terlaksana atau tidak ada buktinya. Padahal orang desa jika sudah mengatakan sesuatu selalu dibuktikan dengan kenyataan.

Pamong Desa mengungkapkan bahwa orang-orang desa kalau sudah berucap, meskipun ucapnya didasarkan pada tradisi, segala sesuatunya pasti dilaksanakan. Mereka ketakutan, jika tidak melakukan apa yang telah menjadi ucapannya. Buktinya upacara Bersih Desa yang memakan biaya tidak sedikit, selalu diusahakan mereka untuk dapat terlaksana setiap tahun. Jadi antara ucapan dan tindakan sama. Fenomena sosial bangsa Indonesia sekarang lagi terpuruk, sebagai akibat krisis berkepanjangan. Harga-harga mulai dari barang-barang, sandang-pangan, sampai pada soal menyekolahkan anak juga mahal. Namun demikian, kenyataannya orang-orang desa masih mampu melakukan upacara Bersih Desa dengan biaya besar.

\section{Pertunjukan Wayang Kulit}

Setiap tahun khususnya tanggal 20 Saban diadakan upacara Bersih Desa pada siang hari serta pertunjukan wayang kulit Lakon Dewi Sri pada malam hari. Baik upacara Bersih Desa maupun pertunjukan wayang kulit tidak dapat dipisahkan (Poloma, 1984: 23). Meskipun demikian, pada tahun 2017 upacara Bersih Desa dilaksanakan tanggal 20 Saban 1438 H (17 Mei 2017), tetapi pertunjukan wayang kulit dilaksanakan tanggal 3 Syawal 1438 H (27 Juni 2017). Sudah tiga tahun ini upacara Bersih Desa dengan pertunjukan wayang kulit dilaksanakan berlainan waktu. Hal ini dimaksudkan agar dengan diadakan pertunjukan wayang kulit pada bulan syawal atau dekat dengan hari raya idul Fitri agar masyarakat yang berasal dari jauh karena merantau dapat silaturahmi (syawalan) sekaligus dapat menikmati pertunjukan wayang kulitdi Desa Geneng. Tradisi itu tidak seutuhnya sama dan sebangun sejak awal hingga masa kini. Seberapa pun kecilnya akan senantiasa terjadi perubahan atau penyesuaian. Perubahan atau penyesuaian itu tidak mustahil berupa pemberian nilai atau makna baru terhadap suatu bentuk tradisi (Ayatrohaedi, 2005).

Pada tanggal 3 Syawal Kurang lebih pukul 10 siang seluruh pearalatan wayang, debog pisang, kotak, kelir, gamelan, dan sound system dipasang di depan rumah bapak Dukuh Desa Geneng. Pergelaran wayang kulit dimulai dengan menghadirkan seorang dalang berasal dari dari Tegalsawah Klaten, yaitu Ki Mulyono. Para dalang wayang kulit dari dulu sampai sekarang yang pernah pentas untuk upacara Bersih Desa antara lain: Ki Sabar dari Trucuk, Ki Warsito Pethuk dari Ceper, Ki Kusni dari Boyolali, dan sekarang Ki Mulyono dari Tegalsawah.

Layar atau kelirnya berwarna putih dengan background di pinggirnya berwarna hitam. Ukuran kelir adalah 2x10 meter persegi. Di bawah kelir terdapat pelepah pisang yang ditata pada sepanjang kelir. Kelir yang dibentang vertikal itu terdapat simpingan wayang, yaitu sekitar 50 wayang dijejer dari tepi kiri yang masing-masing ditancapkan batang pisang menghadap ke kiri, dan 50 wayang dijejer dari tepi kanan yang masing-masing ditancapkan batang pisang menghadap ke kanan. Simpingan wayang di sebelah kiri merupakan golongan tokoh berwatak jahat, sedang di sebelah kanan berwatak baik. Di bagian tengah kelir tidak terdapat simpingan, dan merupakan ruang kosong untuk dipergunakan dalang berkiprah dalam menggerakkan wayang. Batang pisang yang dipergunakan dalang untuk menancapkan wayang terdapat dua macam, yaitu bagian atas untuk menancapkan wayang golongan raja dan bangsawan, dan bagian bawah utuk golongan rakyat jelata. Di atas kepala dalang, sekitar setengah meter, dipasang lampu bolam 50 watt untuk menerangi kelir bagian tengah, yaitu ruang kosong untuk menggerakkan wayang. Lampu ini disebut blencong.

Untuk mengiringi pertunjukan wayang kulit digunakan gamelan Jawa. Instrumen-instrumen gamelan yang dibunyikan meliputi rebab, genderbarung, kendang, kenong, gong, bonangbarung, bonangpenerus, sarondemung, saronbarung, dan saronwayangan. Bentuk instrumen gamelan besar-besar dan terlihat mengkilat, menandakan harga sebuah perangkat musik Jawa yang terbuat dari perunggu itu mahal, sekitar 400 juta rupiah. Para pemain gamelan semuanya laki-laki dewasa umur 35 sampai 50 tahun, kecuali seorang ibu cukup tua menabuh instrumen genderbarung. Di sebelah kanan tempat duduk dalang terdapat tiga orang pesindhen. 
Para penonton terdiri dari bapak-bapak dan pemuda dari Desa Geneng yang sedang duduk di depan panggung pertunjukan wayang kulit. Hadir dalam pertunjukan wayang kulit antara lain Ibu Lurah, Pak Bayan Geneng, Pak RW, Pak RT di seluruh Desa Geneng. Selain itu, dengan mulainya pertunjukan wayang kulit, para penonton juga mulai berdatangan dari luar Desa Geneng yang menambah banyak penonton. Mereka ada yang mengendarai sepeda onthel, sepeda motor, dan ada pula dengan berjalan kaki. Para penonton duduk di serambi-serambi rumah dan halaman, di belakang kelir, bersandar di atas jok sepeda motor, berteduh di bawah pohon mangga, dan terutama anak-anak kecil ikut duduk berdampingan dengan para pemain gemelan di area panggung pertunjukan. Para pengrawit tidak marasa terganggu oleh anak-anak kecil ini. Setiap penonton kadang-kadang terkonsentrasi melihat jalannya pertunjukan wayang, tetapi ada kalanya sambil omong-omongan dengan temannya membicarakan lakon wayang. Dalam melihat pertunjukan ini, hampir setiap penonton melakukanya sambil ngemil (makan snak). Tidak hanya penonton, para pemain gamelan dan pesindhen juga ngemil. Baik dalang, pengrawit, pesindhen, penata sound, dan para penonton hadir di bangsal memiliki tujuan yang sama yaitu ingin ngalap berkah (mengharap rezeki) dalam upacara Bersih Desa.

Pada bagian paling belakang penonton, seorang pengemis tua membawa tongkat ikut melihat pertunjukan wayang dari kejauhan, sambil sekali-sekali dikasih makanan kecil oleh seorang penonton yang merasa iba. Kata orang-orang tua yang menonton pertunjukan wayang, bahwa meskipun sebagai pengemis, setiap ada upacara Bersih Desa, ia selalu menyempatkan datang untuk ikut ambil bagian ngalap berkah. Ia sesungguhnya tidak begitu antusias melihat pertunjukan, karena selain ia berada jauh dari tempat pertunjukan kemungkinan ia sendiri tidak paham cerita wayang. Tidak jauh dari tempat pertunjukan wayang kulit, di tepi jalan dari arah timur, selatan, dan utara dipenuhi orangorang yang berjualan. Mereka adalah para penjual yang selalu setia datang berjualan setiap ada upacara Bersih Desa. Adapun barang-barang yang dijajakan antara lain soto, bakso, mie ayam, nasi rames, nasi pecel, puthu, kacang goreng, es cream, es pop, pakaian, dan mainan anakanak. Barang-barang yang dijajakan itu kebanyakan habis terjual. Kata seorang bakul mainan anak-anak, setiap ada acara seperti ini, dirinya sedang mremo artinya kesempatan untuk mengadu keuntungan yang sebanyak-banyaknya pada hari baik, karena jika tidak ada acara tersebut seorang penjual sulit untuk meraih rejeki. Sementara bakul yang lain mengatakan bahwa keikutandilannya dalam berjualan pada upacara Bersih Desa merupakan bentuk kesetiaannya setiap tahun untuk ngalap berkah.

\section{Lakon Bethari Sri Mulih}

Pertunjukan wayang kulit dalam rangka upacara Bersih Desa selalu menengahkan lakon Dewi Sri. Dewi Sri dianggap sebagai lambang tanaman padi, yang juga men- jadi lambang kemakmuran masyarakat. Masyarakat Desa Geneng yang kebanyakan para petani selalu memiliki harapan Dewi Sri dapat membawa kemakmuran bagi masyarakat Desa Geneng. Wujud kemakmuran itu antara lian, tanah pertanian yang subur. Melalui pertunjukan wayang kulit lakon Dewi Sri yang sakral (Suwarno, 2014) sesungguhnya merupakan bentuk pemuliaan tanaman padi.

Pertunjukan wayang kulit dalam rangka upacara Bersih Desa diketengahkan lakon Bethari Sri Mulih. Dalam cerita Bethari Sri Mulih dikisahkan bahwa dalam sebuah pertemuan agung pejabat negara Amarta sedang membahas persoalan negara. Persoalan itu menyebutkan bahwa Dewi Sri hilang atau pergi meninggalkan negara Amarta. Kepergian Dewi Sri berdampak pada kehidupan rakyat jelata yang menderita kelaparan dan kesengsaraan. Hal ini juga di dalamnya petani gagal panen, kerena banyak padi yang dimakan hama. Selain itu banyak rakyat yang diserang penyakit ganas. Jika sore sakit, paginya meninggal. Jika pagi sakit, sorenya meninggal. Rakyat menderita kelaparan, terserang penyakit, dan banyak yang meninggal dunia. Pendek kata, negara Amarta sedang dilanda pagebluk mayangkara (musibah besar).

Dalam pertemuan agung itu, sang raja mengungkapkan bahwa penyebab terjadinya musibah besar adalah kepergian Dewi Sri dari negara Amarta. Oleh karenannya, rakyat mengharap agar Dewi Sri segara dicari. Himbauan masyarakat itu ditujukan kepada sang raja, yang isinya agar salah satu satriya dari keluarga Pandawa, yaitu Bambang Parabakusuma berangkat meninggalkan Amarta, untuk mencari keberadaan Dewi Sri. Dalam suatu perjalanan, Bambang Parabakusuma bertemu dengan Dewi Sri, dan ia berhasil mebujuknya untuk pulang ke negara Ngamarta. Dengan kepulangan Dewi Sri, seluruh rakyat negara Amarta kembali tentram seperti semula.

Dalam versi lain, lakon yang diketengahkan dalam pertunjukan wayang adalah Sri Sadono-Sri Mulih. Alur ceritanya sama dengan lakon Bethari Sri Mulih. Kisahnya dimulai dari kepergian Dewi Sri menimbulkan melapetaka di negara Amarta. Raja Amarta menyuruh Bambang Sadono untuk mencari keberadaan Dewi Sri. Sang dewi dapat ditemukan Bambang Sadono, dan berhasil diboyong pulang ke Amarta. Seluruh rakyat merasa bahagia. Kebahagiaan itu diperlambangkan bahwa setelah tiba di negeri Amarta, Dewi Sri berubah wujudnya menjadi padi, dan Bambang Sadono berubah menjadi burung sriti. Padi yang subur melambangkan bahwa suatu daerah tercukupi sandang-pangan. Demikian pula burung sriti memiliki sarang lawet melambangkan kekayaan ekonomi suatu daerah. Masyarakat mempercayai Dewi Sri dan Sadono sebagai lambang kesuburan dan kemakmuran. Oleh karena itu, untuk memuja kedua tokoh mitos tersebut, setiap tahun para petani menyelenggarakan upacara Bersih Desa sebagai bentuk rasa syukur mereka menyelenggarakan dengan pentas wayang kulit mengambil cerita dari kisah Dewi Sri. 
Dalam menjalankan lokon Dwi Sri di setiap daerah atau desa sering terjadi pergeseran pertunjukan, entah itu soal judul lakon maupun alur ceritanya. Hal ini tergantung kemampuan dalang dalam mengolah sanggit (garapan dan kreatifitas), dengan tujuan agar masyarakat yang menonton tidak merasa bosan meskipun ceritanya sama. Desa Geneng yang setiap tahunnya mempertunjukkan wayang kulit, meskipun temanya Dewi Sri, tetapi garapan pertunjukannya selalu berbeda.

Terjadinya pergeseran cerita atau lain versi tentang lakon Dewi Sri, karena setiap desa atau daerah memilki ciri-ciri tradisi sendiri, dan tergantung dari potensi lokal yang mewadahinya. Seperti dalam pepatah: "lain ladang lain belalang, lain lubuk lain ikannya", atau dalam ungkapan Jawa: desa mawa cara, kutha mawa tata. Dengan perbedaan tradisi ini, menjadikan Indonesia kaya beraneka ragam budaya. Namun, bagi petani yang penting dapat meruat sekaligus memuliakan tanaman padi agar tetap subur (Sayuti, 2016).

\section{SIMPULAN}

Bentuk pemuliaan tanaman padi merupakan kegiatan masyarakat desa untuk memposisikan tanaman padi agar selamat, sehat, subur, dan mendatangkan kesejahteraan manusia. Di dalam kegiatan masyarakat desa itu, tidak hanya tanaman padi saja yang dimuliakan, akan tetapi juga masyarakat petani yang menanam padi itu sendiri. Masyarakat petani juga ingin selamat, sehat, sejahtera, dan dapat menjaga hubungan harmonis dan menjaga keseimbangan antara manusia daan manusia, manusia dan alam, manusia dan makhluk alam gaib, serta manusia dan Tuhan Yang Maha Esa.

Bentuk pemuliaan tanaman padi melalui pertunjukan wayang kulit lakon Dewi Sri dalam upacara Bersih Desa adalah aktivitas budaya yang terdiri dari: Pertama, tata cara pemuliaan tanaman melalui upacara Bersih Desa yang disertai dengan berbagai persyaratan dan doa merupakan bentuk syukur manusia kepada Tuhan. Pemberian Tuhan berupa sawah yang luas, padi yang subur, dan masyarakat yang sehat, selamat dan sejahtera ditanggapi manusia dengan cara bersyukur melalui uapacara Bersih Desa.

Kedua, tata cara pemuliaan tanaman padi adalah dengan mempresentasiknan Lakon Dewi Sri dalam pertunjukan wayang kulit, yang mengisahkan bahwa kehidupan selain itu manusia. Dalam pertunjukan wayang kulit selalu dikisahkan, ketika Dewi Sri meninggalkan kerajaan Amarta, maka situasi negara menjadi kacau-balau karena banyak musibah. Setelah Dewi Sri dapat ditemukan dan kemudian dibawa pulang, negara Ngamarta menjadi aman lagi. Hal ini memberikan makna bahwa tanaman padi menjadi pokok dalam kehidupan manusia, yang harus dijaga, dipelihara, dan diselamatkan. Dengan demikian langkah syukur manusia kepada Tuhan melalui pemuliaan tanaman padi yang diwujudkan dengan upacara Bersih Desa dan pertunjukan wayang kulit dengan lakon Dew Sri merupakan usaha manusia untuk menjaga hubungan, yaitu antara manusia dan Ttuhan (secara vertikal) dan antara manusia dan manusia (secara horizontal).

\section{DAFTAR RUJUKAN}

Ayatrohaedi. (2005). Percik Budaya Sebuah Renungan Kebudayaan. Bogor: Penerbit Akademia.

Hughes-Freeland, Felicia. (1998). Ritual, Performance, Media. New Tork: Routledge.

Moertono, Soemarsaid. (1968). State and Statecraft: A Study of the Later Mataram Period, $16^{\text {th }}$ to $19^{\text {th }}$ Century Modern Indonesian Project. Ithaca, New York: Cornell University.

Nene, YL. (2012). "Environment and Spiritualism: Integral Parts of Ancient India Literature and Agricultural." Asian Agri-History, Vol. 16, No. 2, 123-141.

Poloma, Margareth M. (1984). Sosiologi Kontemporer. Terjemahan. Jakarta: PT Rajawali.

Riani, Cinta. (2012). "Ruwatan Massal melalui Pergelaran Wayang Kulit." Harmonia: Jornal of Art and Art Research, Vol. 12, No. 1, 14-23.

Sayuti, Suminto A. (2016). "Sastra Yang Meruat Bumi." Makalah disampaikan dalam Konferensi Internasional Kesusastraan (KIK) ke-25, di Fakultas Bahasa dan Seni, Universitas Negeri Yogyakarta, 13-14 Oktober.

Simatupang, GR Lono L.( 2006). “Jagad Seni: Re"eksi Kemanusiaan". Makalah dalam Workshop "Seni Tradisi Lisan Sebagai Wahana Komunikasi yang Sangat Efektif di Tengah Masyarakat yang Sedang Berubah. Yogyakarta: Balai Kajian Sejarah dan Nilai Tradisional, 6 September.

Sriwulan, Wilma. (2014). "Struktur, Fungsi, dan Makna Talempong Bundo dalam Upacara Maanta Padi Saratuih." Resital: Jurnal Seni Pertunjukan, Vol. 15, No.1, 52-70.

Suwarno. (2014). "Fungsi Wayang Klitik Wonosoco, Undaan Kudus Jawa Tengah dalam Ritual Bersih Desa". Patrawidya: Seri Penerbitan Penelitian Sejarah dan Budaya, Vol. 15, No. 4, 621-640.

Turner, Victor. (1982). From Ritual To Theatre: The Human Seriousness of Play. New York: P.A.J. Publication.

Yuniarso, Agus. (2012), Merti Desa, Ungkapan Syukur Kaya Makna. Yogyakarta: Kabare Yogya. 